\title{
How Ports Can Improve Their Sustainability Performance: Triple Bottom Line Approach
}

\author{
๑ Nergis Özispa
}

Dokuz Eylul University Faculty of Maritime, Department of Maritime Business Administration, Izmir, Turkey

\begin{abstract}
Ports, located at the center of the world trade, are shown to be one of the harmful industries to the environment due to their characteristics such as the amount of waste they produce, harmful emissions, and noise pollution they cause. That makes ports also one of the important industries to reduce this harm caused by itself. In order to work toward reducing this harm, it is thought that the factors that cause the most damage should be determined first, then the steps for reducing the damage caused by these factors should be found. Hence, to detect the degree of importance of port sustainability criteria and decide the sustainability performance of the chosen port is determined as the primary aim of this study. In order to achieve this objective, the sustainability performance of an international port has been examined for seven years, based on financial, environmental, and social dimensions of sustainability with the analytical hierarchy process and technique for order preference by similarity to ideal solution methods. Accordingly, the possible reasons of port sustainability performance inequalities for all three dimensions of sustainability have been discussed. This study concludes that "materiality model" and "Fatal 5 program" developed by APM Terminals have remarkable positive effects on sustainability performances of ports.
\end{abstract}

\section{Keywords}

Port sustainability, Sustainability performance measurement, Multicriteria decision making

\section{Introduction}

Sustainability has become a policy concept with its inclusion in the 1987 Brundtland Report [1]. Since then, several areas in academic literature such as social sciences, managerial sciences, environmental science, or technical science have defined the term in line with their expertise. Hence, it is possible to find various definitions of sustainability in literature [2]. However, finding a consistent definition of sustainability in literature is still one of the biggest challenges as most of the sustainability studies do not serve a definition of sustainability, even they evaluate it [3]. In its simplest form, sustainability concept is the management of all sorts of resources to continuing at least quality of life for the current generation and also for future generations [4]. The most cited sustainability definition was created in 1987 in the Brundtland Report, which is; "Meeting the needs of the present without compromising the ability of future generations to meet their own needs [5]".
In addition to the lack of a clear and agreed sustainability definition, environmental and financial dimensions of sustainability are considered rather than social dimensions [6]. In 1997, Elkington [7] revealed the need to evaluate the performance of three basic dimensions of sustainability, i.e., environmental, economic, and social dimensions, to make sustainability operational and named this as the "triple bottom line approach". The environmental sustainability term was presumably invented by the World Bank scientists although, the term "environmentally sensitive development" was used in the beginning [8]. The environmental dimension of sustainability includes the reduction of people's negative impacts on environment and protection of nature and ecosystems. Environmental sustainability emphasizes renewable and non-renewable resources globally, and human beings must act sensitively to the use of all resources [9]. Value creation and the financial situation of firm's sustainability activities and their impacts on the company are two main focus areas of the financial dimension of

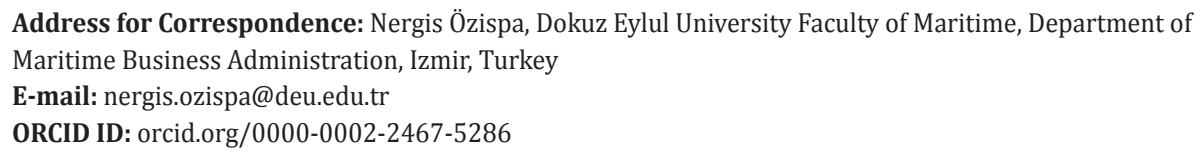

To cite this article: N. Özispa, "How Ports Can Improve Their Sustainability Performance: Triple Bottom Line Approach," Journal of ETA Maritime Science, vol. 9, pp. 41-50, 2021.

${ }^{(C)}$ Copyright 2021 by the Journal of ETA Maritime Science published by UCTEA Chamber of Marine Engineers 
sustainability [10]. Financial sustainability concerns the cost-benefit analysis of an industry that aims to be profitable while producing products and services that contribute to society [11]. Some economists simplify the definition of financial sustainability concept as "maximization of the benefit from consumption and the increase of wealth [12]." The social dimension of sustainability primarily focuses on human development. It also deals with cultural and social necessities like the permanent establishment of basic requirements such as food and shelter, security, equality, health, freedom, education, and employment [9].

\section{Literature Review}

Port sustainability issues have been studied in many different fields of sustainability such as development, performance, management, port construction, sustainability indicators, reporting, measurement, etc.

Daamen [13] analyzed sustainable development in ports within the USA and Europe; he took Rotterdam and Hamburg ports and these cities as a sample with the aim of "finding a new typology and new interpretation of the contemporary port-city interface". At the end of the study, the author demonstrated about the Hamburg and Rotterdam cities port-city interface situations and found two objectives which are to attain public support in order to achieve short and long term objectives and to determine the realization degree of these objectives on the local level. A case study conducted by Abood [14] in 2007 that took New York port as a case and demonstrate how to fit more advanced programs into a sustainability framework using determined eight operational topics "dredging, ballast water, habitat restoration, air quality, water conservation, energy conservation, material conservation and waste handling". As a result, the author proposed a rating system in line with given operational topics and designed only for port activities [14]. Lam and Van de Voorde [15] worked on the sustainable development identifiers and determined the influence degree of these identifiers of sustainable development for port cities with their survey, conducted with 381 people at Torkaman city. As a result, civil rights were determined as the most effective, while political identifiers were determined as the least effective ones [15].

Multicriteria decisions making (MCDM) methods were used by Lirn et al. [16] to measure the port sustainability performance with the sample of three major container ports in China. The most critical port sustainability indicators determined in this study as "avoiding pollutants during cargo handling and port maintenance, noise control, and sewage treatment [16]".

In 2005, Peris-Mora et al. [17] proposed a new environmental sustainability system for ports and created sustainable environmental management indicators system. They proposed seventeen indicators based on their results from case studies and multicriteria analysis methods [17].

\section{Methodology}

MCDM is a method that used in sustainability studies, especially the ones that measure sustainability performances. MCDM methods, defined by Ç. Inar [18], as the whole set of procedures that try to help the decision makers to reach the solution wanted by addressing complex decision problems in a scientific and analytical framework. Also, it is extensively used to solve the problems of multiple and conflicting goals [19]. To measure sustainability performance, indicators are developed and used predominantly [20], providing a useful framework while evaluating multiple variables together in one of the features of MCDM methods. Thus, analyzing the three dimensions of sustainability together can be achieved with these methods [21]. In the present study it has been decided to use MDCM methods.

In this study, APM Terminals is chosen as a case company, first started to serve as a general cargo facility in Port of New York in 1958, and was officially established as an independent division in Maersk in 2001. Today, it operates as one of the world's most comprehensive port networks with 78 terminals and 22,000 industry professionals globally [22]. Thus, it is considered that the selection of the sample company will represent the port sustainability activities in the world in the most comprehensive way possible. Also, its sustainability and annual reports can be obtained from their main website, and the subsequent data about main sustainability criteria can be accessed from the reports between 2011 and 2017. After 2017, their reporting policy has changed, and they started to publish their data as Maersk Group. Hence the data between 2011 and 2017 has been used in this specific study.

To reach the aim of the study, as defined to detect the importance of the degree of port sustainability criteria and decide the port sustainability performance of the chosen port, at first, indicators that focused on port sustainability measurement in current literature have been examined. Then, sustainability and annual reports of seven years period of the chosen international port have been analyzed to obtain data that meet indicators compiled from the literature. Besides, the financial, environmental, and social dimensions of sustainability are examined in sustainability performance measurement. Six indicators of environmental dimension [Greenhouse gas (GHG) emissions, sulfur oxides emissions (SOx), nitrogen oxides emissions (NOx), water consumption, electricity consumption, fuel consumption], one indicator of financial dimension (Revenue), and two indicators of social dimension (Fatalities and injury/ 
sickness) are the suggested port sustainability indicators in the literature by $[17,23-25]$. Other indicators used in the analyses compiled by the author via sustainability and annual reports of the port. In order to measure these dimensions, fifteen indicators in total were used as measurement values, including four financial, six environmental, and five social dimensions. Port sustainability dimensions gathered from the literature are given in Table 1.

With these indicators, the sustainability performances of port measured via the analytical hierarchy process (AHP) and technique for order preference by similarity to ideal solution (TOPSIS) methods from MCDM. First, the AHP method is used to determine the weights of sustainability subdimensions, then the reduction of multidimensional data to a single dimension is ensured. After the AHP process, using the TOPSIS method, the most successful years and indicators are achieved on a yearly basis for each main dimension of sustainability and discussed the possible reasons for these successes.

In MCDM problems, the judgments about the subject are learned by discussing with the persons concerned about the subject via evaluation forms. In order to obtain consistent outcomes, the interviewees need to be expert or moderately expert about the subject. Consequently, the results of the AHP are based entirely on the judgment of these persons $[26,27]$. Once the dimensions of sustainability have been identified, an evaluation form has been prepared, containing three dimensions of sustainability for consultation. These evaluation forms were filled by industry experts and academicians. Within the scope of the study, 10 experts were interviewed. The experts who completed the evaluation form consist of academicians experienced in sustainability and port subjects, finance and banking sector employees, environmental and chemical engineers, and they were interested in sustainability and job security. Within the scope of the study, data collection forms related to their field of expertise were sent to each expert, allowing each expert to make binary comparisons related to their field of expertise. Afterward, the method was continued by taking the geometric average of the data obtained for each dimension during the application of the AHP method. Detailed information about these experts who helped in the AHP weighting process of the study is given in Table 2.

Table 1. Dimensions and subdimensions of port sustainability

\begin{tabular}{|c|c|c|c|c|c|}
\hline \multicolumn{2}{|c|}{ Environmental dimension indicators } & \multicolumn{2}{|c|}{ Financial dimension indicators } & \multicolumn{2}{|r|}{ Social dimension indicators } \\
\hline$E n v_{1}$ & Greenhouse gas emissions & $\mathrm{ECO}_{2}$ & Revenue & Soc $_{1}$ & Number of employees \\
\hline $\operatorname{Env}_{2}$ & Sulfur oxides emissions & $\mathrm{ECO}_{2}$ & Profit for the year & $\mathrm{Soc}_{2}$ & $\begin{array}{c}\text { Ratio of women employees to total number of } \\
\text { employees }\end{array}$ \\
\hline $\mathrm{Env}_{3}$ & Nitrogen oxides emissions & $\mathrm{ECO}_{3}$ & Tax for the year & $\mathrm{Soc}_{3}$ & $\begin{array}{l}\text { Ratio of women employed in senior management to } \\
\text { total number of employees }\end{array}$ \\
\hline$E_{n v_{4}}$ & Water consumption & $\mathrm{ECO}_{4}$ & Operating Profit & $\mathrm{Soc}_{4}$ & Fatalities \\
\hline $\operatorname{Env}_{5}$ & Electricity consumption & & & $\mathrm{Soc}_{5}$ & Lost-time injury and sick leave accidents \\
\hline Env $_{6}$ & Fuel consumption & & & & \\
\hline
\end{tabular}

Table 2. Detailed information about the experts

\begin{tabular}{|c|c|c|c|}
\hline Expert area and information about the experts & 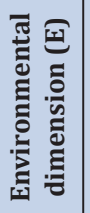 & 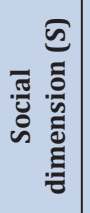 & 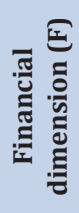 \\
\hline Port Sustainability (Department of Industrial Engineering, Narvik University College, Narvik, Norway) & $\sqrt{ }$ & $\sqrt{ }$ & $\sqrt{ }$ \\
\hline Sustainability (Department of Maritime Business Administration, Dokuz Eylul University, Izmir, Turkey) & $\sqrt{ }$ & $\sqrt{ }$ & $\sqrt{ }$ \\
\hline Port (Department of Maritime Business Administration, Dokuz Eylul University, Izmir, Turkey) & $\sqrt{ }$ & $\sqrt{ }$ & $\sqrt{ }$ \\
\hline Environment and Job Security (Environmental Engineer and Job Security Specialist in Borusan Mannesmann, Bursa, Turkey) & $\sqrt{ }$ & $\sqrt{ }$ & \\
\hline Environmental Sustainability (Chemical Engineer, 4K Kimya Sanayi, Izmir, Turkey) & $\sqrt{ }$ & $\sqrt{ }$ & \\
\hline Finance (QNB Finansbank, Izmir Branch Manager, Izmir, Turkey) & & & $\sqrt{ }$ \\
\hline Finance (QNB Finansbank, Authorized Assistant, Izmir, Turkey) & & & $\sqrt{ }$ \\
\hline Finance (T.C. Ziraat Bank, Individual Customer Relationship Authority, Bursa, Turkey) & & & $\sqrt{ }$ \\
\hline Finance (Vakıfbank, Controller, Istanbul, Turkey) & & & $\sqrt{ }$ \\
\hline Finance (Vakıfbank, Bank Inspector, Kutahya, Turkey) & & & $\sqrt{ }$ \\
\hline
\end{tabular}




\subsection{Mathematical Infrastructure of AHP and TOPSIS Methods}

AHP is one of the multicriteria decision making methods in which the eigenvalue approach is used for binary comparisons [26]. The AHP method helps to create consensus by reducing the ideas of a group to a single result and provides the final solution by evaluating the geometric averages of binary comparisons for each variable [26]. In this direction, weights of the criteria $[\mathrm{w}]$ were obtained in binary comparisons. Decision makers do not have to make numerical comparisons; they can make a comparison with the words [28]. Binary comparisons usually use the 1-9 scale of Saaty [29], as shown in Table 3.

Table 3. Importance rating table used in comparisons [29,30]

\begin{tabular}{|c|c|c|}
\hline $\begin{array}{c}\text { Importance } \\
\text { rating }\end{array}$ & Definition & Statement \\
\hline 1 & Equally important & $\begin{array}{c}\text { Both factors have the same } \\
\text { precaution }\end{array}$ \\
\hline 3 & $\begin{array}{c}\text { Important in middle } \\
\text { grade (less superior) }\end{array}$ & $\begin{array}{c}\text { According to experience and } \\
\text { judgment, a factor is more } \\
\text { important than the other }\end{array}$ \\
\hline 5 & $\begin{array}{c}\text { Important in strong } \\
\text { grade (superior state) }\end{array}$ & $\begin{array}{c}\text { One factor is strongly more } \\
\text { important than the other }\end{array}$ \\
\hline 7 & $\begin{array}{c}\text { Important in very high } \\
\text { grade (very superior } \\
\text { state) }\end{array}$ & $\begin{array}{c}\text { One factor is strongly more } \\
\text { important at a higher level } \\
\text { than the other }\end{array}$ \\
\hline 9 & $\begin{array}{c}\text { Important in absolute } \\
\text { grade (absolute } \\
\text { superiority) }\end{array}$ & $\begin{array}{c}\text { One of the factors is very } \\
\text { important to the other }\end{array}$ \\
\hline $2,4,6,8$ & $\begin{array}{c}\text { Intermediate values } \\
\text { Mutual } \\
\text { values }\end{array}$ & $\begin{array}{c}\text { If factor i has one of the above numbers assigned to it } \\
\text { when compared to factor } \mathrm{j} \text { (x), then j has the reciprocal } \\
\text { value when compared with i } 1 / \text { x) }\end{array}$ \\
\hline \multicolumn{2}{|c|}{$\begin{array}{c}\text { The preference between } \\
\text { the two factors is the } \\
\text { ratios found in the above } \\
\text { explanations }\end{array}$} \\
\hline
\end{tabular}

When the AHP is analyzed, the upper limit is set at 9 (shown in Table 2) as this method produces good results, particularly for $\mathrm{n}<10$ criteria [31]. In other words, while solving MDCM problems with AHP method, the number of criteria exceeds 9, and big inconsistencies can occur.

In the comparison matrix, all comparison values are positive, and diagonal elements take the value 1 as it is compared with the criterion itself [32].

Relative weights are calculated using the $\mathrm{w}$ eigenvector based on $\lambda$ maks, providing the equation as $A w=\lambda$ maks.

Besides, two coefficients are used, consistency index (CI) and consistency ratio (CR), to ensure the consistency of subjective perceptions and the relative weights. The following formula 1 is used to calculate CI:
$\mathrm{CI}=(\lambda$ maks $-\mathrm{n}) /(\mathrm{n}-1)$

Where $\lambda$ maks is the greatest eigenvalue and $\mathrm{n}$ is the total number of properties (criterion). In order to obtain a reliable result, the $\mathrm{CI}$ value must not exceed 0.1 [32]. The CR can be obtained using the following formula 2 :

$\mathrm{CR}=\mathrm{CI} / \mathrm{RI}$

Where RI stands for "random value index". Table 4 shows RI values of different element numbers (n).

For reliable and realistic results, the consistency ratio (CR) $<0.1$ is expected. Some researchers indicated that a maximum number of 0.2 is the maximum acceptable value for this boundary value [32].

TOPSIS method, which is one of the multifeatured decision making methods, enables the values of the examined variables to be converted mathematically into a single score and evaluated as a more concrete output [33]. In this method, alternative options are compared according to certain criteria and ideal distances between maximum and minimum values that the criteria can take. The first step to be used in the TOPSIS method is creating the decision matrix. decision maker demonstrates decision points in rows and columns, showing the factors in this matrix [33]. The decision matrix was then formed, normalized, and the weighing process was completed following the rules of the method. Once the weighted normalized matrix (V matrix) has been obtained, the maximum and minimum values for each column are determined; these values are named ideal solution values and negative ideal solution values [33].

\section{Results}

Table 5 shows the CR (consistency ratio) values of each dimension.

According to Aykın [34], the CR values must be smaller or equal to $10 \%$ to adopt the inconsistency is acceptable. Otherwise, for $\mathrm{CR}>10 \%$, the results are assumed unacceptable. Hence, for $\mathrm{CR}$ value $\leq 0.1$, the comparisons of matrix is considered consistent in AHP method [35], as evident from Table 5.

Table 4. Random value index [32]

\begin{tabular}{|c|c|c|c|c|c|c|c|c|c|c|}
\hline $\mathbf{N}$ & $\mathbf{1}$ & $\mathbf{2}$ & $\mathbf{3}$ & $\mathbf{4}$ & $\mathbf{5}$ & $\mathbf{6}$ & $\mathbf{7}$ & $\mathbf{8}$ & $\mathbf{9}$ & $\mathbf{1 0}$ \\
\hline $\mathbf{R I}$ & 0 & 0 & 0.58 & 0.90 & 1.12 & 1.24 & 1.32 & 1.41 & 1.45 & 1.49 \\
\hline
\end{tabular}

Table 5. Reliability of results

\begin{tabular}{|c|c|}
\hline & CR value \\
\hline Dimensions of sustainability & 0.020807 \\
\hline Financial dimension & 0.039998 \\
\hline Environmental dimension & 0.032870 \\
\hline Social dimension & 0.053100 \\
\hline
\end{tabular}




\subsection{Results of AHP}

According to the results, the financial dimension of sustainability is defined as the most important dimension from the perspective of the ports; environmental dimension and social dimension of sustainability followed it, respectively.

Between the subdimensions of financial dimension, operating profit of the ports chosen as the most important one. In environmental dimension, the amount of water consumption in ports and in social dimension, fatalities in ports are seen as the most important subdimensions of sustainability. Figure 1 presents the order of importance and priority vector (PV) values of each dimension and their subdimensions.

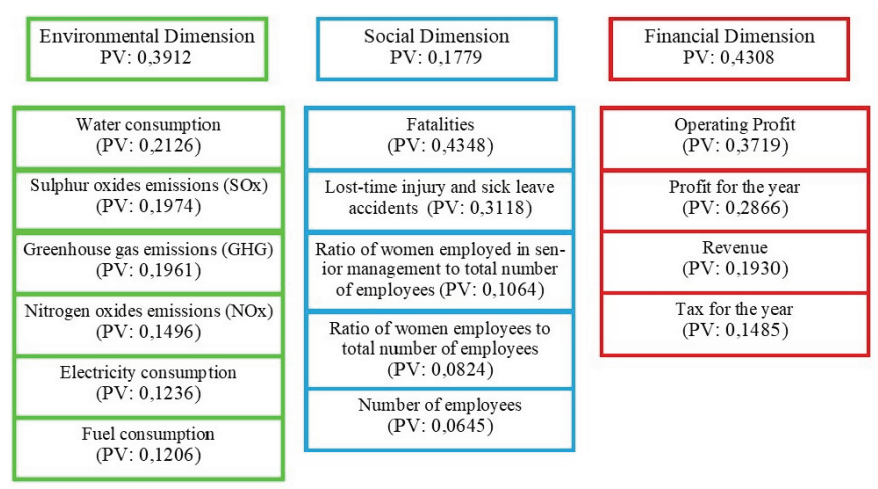

Figure 1. Importance degree of port sustainability criteria

GHG: Greenhouse gas, PV: Priority vector, $\mathrm{SO}_{\mathrm{X}}$ : Sulfur oxides emissions, $\mathrm{NO}_{\mathrm{X}}$ : Nitrogen oxides emissions

With the analytic hierarchy process, first decision matrices have been created for all dimensions for sustainability. It is the geometric mean results of the binary comparison evaluations of the given experts. Second, normalized matrices have been created, and priority vectors of each dimension and their subdimensions obtained. In order to measure the reliability of these weights of dimensions, CR values of each dimension and their subdimensions have been calculated using the formulas $\lambda$ max, $\mathrm{CI}=(\lambda$ maks-n $) /$ (n-1) and CR $=\mathrm{CI} / \mathrm{RI}$ [32]. RI values given in Table 4 have been used to obtain $\mathrm{CR}$ values. After defining $\mathrm{CR}$ values as reliable, priority vector values of each dimension and their subdimensions were used as criteria weights in the TOPSIS process.

\subsection{Results of TOPSIS}

After deciding the order of importance and PV values of all dimensions and their subdimensions, annual reports and sustainability reports between the years 2011 and 2017 of APM Terminals were analyzed. The APM Terminals score for each year and each subdimension were identified, and decision matrices of three dimensions of sustainability were developed. Then, normalized matrices were calculated using the values obtained in AHP. After defining ideal and negative ideal solution values, ideal and negative ideal distances were calculated. At the end, the formula $\mathrm{Ci}^{\wedge *}=$ $(\mathrm{Si}-) /[(\mathrm{Si}-)+(\mathrm{Si}+)][33]$ was used to calculate the relative proximity of the ideal solution, and the values obtained by years are shown in Figure 2, 3 and 4.

Based on the values gathered from sustainability and annual reports of APM Terminals and PV values obtained from the AHP, the results of financial sustainability performance of APM Terminals between the years 2011 and 2017 are calculated and visualized, as shown in Figure 2. The results show that 2014 was the most successful year for APM Terminals in the perspective of financial sustainability. After 2014, the financial sustainability performance of the port has steadily declined; the sharp decline of 2017 is particularly noteworthy.

While calculating TOPSIS results of the performance of environmental sustainability of APM Terminals, the values related to subdimensions of the environmental dimension of sustainability were gathered via the annual and sustainability reports of APM Terminals. However, subdimensions, which

\section{ECONONIC DIMENSION}

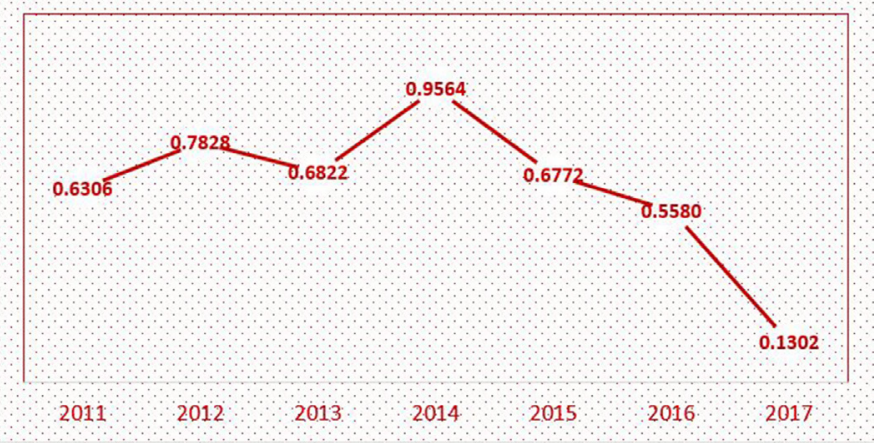

Figure 2. TOPSIS results of financial dimension

TOPSIS: Technique for order preference by similarity to ideal solution

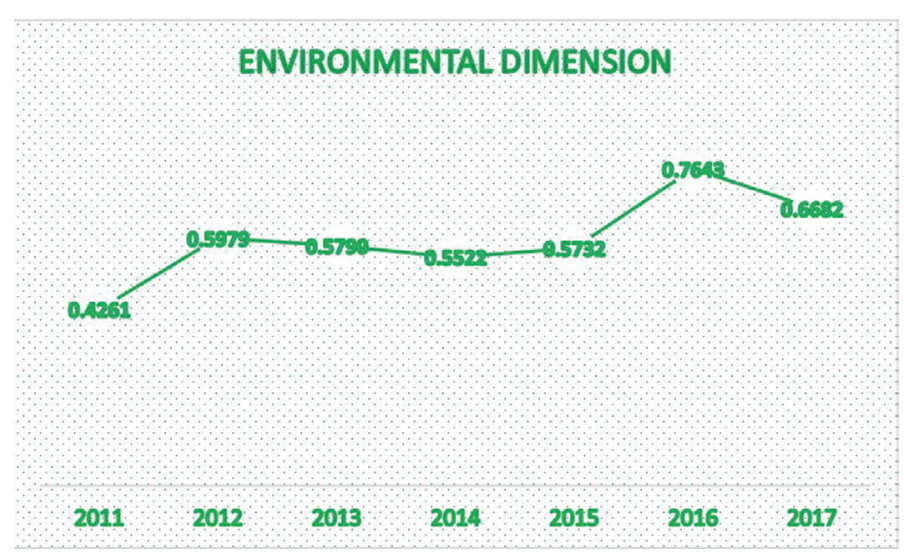

Figure 3. TOPSIS results of environmental dimension

TOPSIS: Technique for order preference by similarity to ideal solution 
are considered under the environmental dimension of sustainability, will give positive results when they receive negative values. For example, GHG emission amount of a port is equal to 5,000 tons in one year and 3,000 tons in the next year. It is considered a positive directional change and a success, even though the mathematical value is decreased. Therefore, negative versions of all environmental dimension values obtained from the annual and sustainability reports of APM Terminals are used for calculation. As a result, the environmental sustainability performance of APM Terminals did not change much between 2012-2015 and continued to be stationary. Besides, the performance increases in 2012 and 2016 is considered to be remarkable.

While calculating the social dimension of sustainability in APM Terminals, two subdimensions value could not be reached in any reliable source published by APM Terminals. These are: 2011 values of the ratio of female employees in total employees and ratio of female employees work as a manager in total employees, and 2012 value of the ratio of female employees work as a manager in total employees. So these values filled up with the geometric means of the same values of other years. Also, due to the same reason that explained in the environmental dimension results of the study, the fatalities, lost-time injury, and sick leave accidents subdimensions values of social dimension were used with their negative versions. The result of social sustainability performance at APM Terminals is shown in Figure 4. The sharp decreases in 2014 and 2017 and the same increase in 2016 are considered remarkable.

Possible reasons for the performance of all dimensions of sustainability that increase and decrease will be analyzed in detail in the discussion of this study.

\section{Discussion}

In this part of the study, sustainability and annual reports of APM nalsrmi and sustainability and annual reports of

\section{SOCIAL DIMENSION}

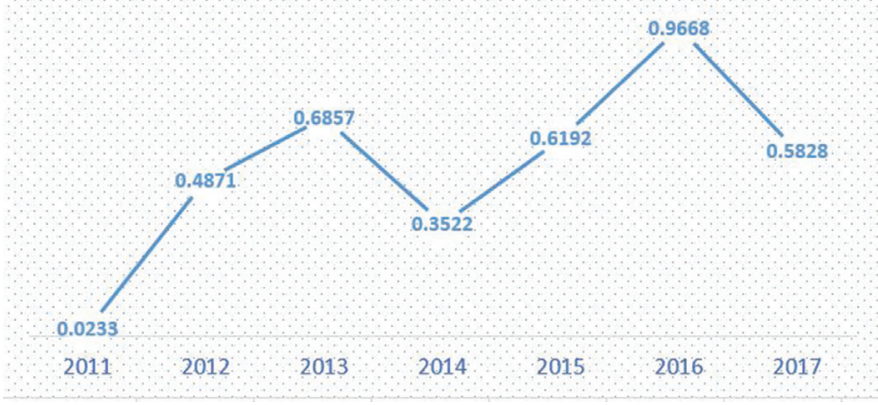

Figure 4. TOPSIS results of social dimension

TOPSIS: Technique for order preference by similarity to ideal solution
APM Terminal related parts of Maersk Group between the years 2011 and 2017 reviewed again to gather the possible reasons for the sharp increase and decrease in the sustainability performance of APM Terminals.

In 2011, APM Terminals defined their sustainability framework 12; the main objective that defined detailed as; "no harm to people, protect the environment, respect the neighbors, use energy and resources efficiently, lift global trade, publicly report the performance, promote best practices, manage health, safety, security, environmental and corporate responsibility (HSSE\&CR) issues as critical business activity and promote a culture in which all employees share this commitment [36]". In 2012, they had four core areas to reach sustainability, i.e., "health, safety and security, responsible business, environment and social responsibility [37]". Zero significant spills for environment, $25 \%$ reduction in $\mathrm{CO}_{2}$ emissions for climate change and increase diversity, and zero fatalities for the social dimension of sustainability were the 2013 goals of APM Terminals. The same year they also developed a materiality matrix that involved environmental and social issues of sustainability in gaining insight into which sustainability issues are especially important to their facilities [38]. Contrary to the opinion of Henri and Journeault [6], which was included in the literature section of this study that the social dimension of sustainability is generally neglected. This materiality matrix was considered important in terms of the importance that APM Terminals attach to the environmental and social dimensions of sustainability. In 2014, APM Terminals created an infographic highlighting some positive and negative impacts that their investments on the local area in terms of sustainability to minimize negative impacts and maximize positive impacts. With this system, they realized their negative impacts on ecology, traffic, land acquisition, etc. Their positive effect on wealth, employment, increased efficiency, reliability, etc.; this infographic worked like a roadmap for their sustainability practices [39].

\subsection{Financial Dimension}

In 2011, the increasing need for additional port capacity for the coming years had been forecasted by most industry experts, and APM Terminals already had long term growth prospects. That year it secured a few new investments in growth markets and took over operations in some regions, such as port of Callao, port of Peru, etc. During 2011, APM Terminals had 7 port projects in the development phase [36]. The expansion into a high growth market continued in 2012. Also, in 2012, APM Terminals launched a Global Transformation Project to increase operational performance, aiming to increase efficiency by 15\% [40]. Even if Hurricane Sandy and some local political unrest or labor issues negatively affected the financial operations 
in some APM Terminals [40], it still achieved success in financial sustainability performance in 2012 (Figure 2). In 2013, two separate data were published by the port on their cash flow from operating activities that contradicted each other. According to the 2012 sustainability report, the cash flow from operating activities was given as 975 million USD; however, in 2013, the same was given as 910 million USD $[37,38]$. AHP results of this study gave this subdimension as the most important one; the author decided to use the 2012 data as the data provided in the 2012 report, as it will significantly impact the results. And this decrease (975 million USD to 923 million USD) in cash flow from operating activities, the most important subdimension, has emerged as the reason for the decrease in the financial sustainability performance of the port in 2013. However, 2014 was the most successful year for the APM Terminals in terms of financial sustainability. The success was mostly impacted by the sale of some APM Terminal facilities worldwide as that year, tax payments of the port increased significantly, and cash flow from operating activities was affected by it [41]. It is observed that the financial sustainability performance of the port has decreased continuously after 2014. Due to the global market conditions, the fall in oil prices in 2015 has had an unfavorable effect on several APM Terminals, especially those in oil-dependent markets. When added to these in the divestments of 2014, the year 2015 was not a very financially good year for APM Terminals [42]. In 2016, the port industry faced structural challenges due to larger container vessels and shipping lines consolidations and alliances. Hence, APM Terminals also faced these challenges in some of its important markets. As a result, its revenues and cash flows from operating activities decreased considerably [43]. Eight contracts of APM Terminals terminated in 2017 while they started 29 new contracts and faced various commercial challenges in that year. At the end, the operating profit of APM Terminals was reported as negative in 2017 due to the challenging market conditions and start-up costs of projects under implementation [44]. As a result, the financial sustainability performance of the port has reached rock bottom.

\subsection{Environmental Dimension}

APM Terminals achieved to save 1,652,715 liter of diesel fuel, reduce $\mathrm{CO}_{2}$ emissions by 3,185 metric tons with the conversion of diesel-powered rubber tired gantry cranes to hybrid engines capable of using both diesel fuel and electricity in 2011 in some pilot areas. In addition to that, some APM Terminals in Europe have converted their power supplies to $\mathrm{CO}_{2}$ neutral and wind generated electricity sources [36]. In 2012, APM Terminals identified three primarily important risk categories; "emissions to air, soil and water pollution and biodiversity" and they have committed themselves to reduce these risks in their terminals. Therefore, they contributed to developing some guidance prepared by the EU Ports European Group, UN Environment Programme, or World Conservation Monitoring Centre [37]. All these efforts to improve environmental sustainability performance were first observed in 2012 results (Figure 3) and led to improvement and development that will continue until 2016. In 2013, they focused especially on spills and emissions to air, and they developed a new reporting guidance for energy consumption, waste, water, and air emissions. In short, they determined the points on which they would focus in parallel with the results obtained from their materiality matrix in 2013. APM Terminals experienced small amounts of decrease in their environmental sustainability manners in 2014. When compared the 2013 their electricity consumption, energy consumption, GHG emissions, waste generations and water consumptions increased. Although these increases caused the small decrease that we saw in Figure 3, APM Terminals took action to prevent this from happening next year and identified 6 situations that needed urgent attention such as "emergency/spills response, management of chemicals and other dangerous substances, energy consumption and carbon emissions, water consumption, waste noise and light pollution (in locations in close proximity to local communities and/or biodiversity hotspots) [37]". The reports of 2015 do not contain very detailed information on efforts to improve environmental sustainability in APM Terminals. However, the world's first fully automated and emission-free, sustainable powered container terminal was launched in 2015 by APM Terminals [42]. Even though we do not encounter an unusual method to increasing environmental sustainability performance between 2013 and 2016. APM Terminals, which combined the reporting standard with the Maersk Group in 2016, made a radical change in their systems. Their materiality assessment matrix, first developed in 2012, updated and published since then. However, in 2016, the matrix was changed to a materiality model that provides better information about why and how an issue is material and how it can best be managed, as the matrix is about the expression of importance, not how to manage it. Their model consisted of three main materiality dimensions; responsibility, shared value, and risk [45]. With the transition from materiality matrix to materiality model, they reported the best environmental sustainability performances ever. Unfortunately, the sustainability report published in 2017 was an integrated report of APM Terminals and Maersk Group; thus, there is no clear information about APM Terminals environmental performance of that year. Hence it is not possible to explain the slight decrease demonstrated in Figure 3. But, according to the integrated report of oil spills and harmful releases of 
air $\left(\mathrm{CO}_{2}, \mathrm{NO}_{\mathrm{x}}, \mathrm{SO}_{\mathrm{x}}\right)$, it is demonstrated as a priority from the environmental perspective.

\subsection{Social Dimension}

In 2011, a safety leadership workshop was conducted as APM Terminals safety strategy, and four high risk areas were identified to develop an action plan. The same year, to improve safety and awareness of social sustainability issues via training and demonstrations of Global Safety Day celebrated in all APM Terminals [36]. In 2011 ten, and 2012 five fatal accidents occurred in various APM Terminals. Thus, in 2012 safety had become the first priority for APM Terminals. Four global safety commitment was created (safety is our license to operate, safety has no hierarchy, safety means no compromise, and safety is not optional) in 2012. A safety activist who has a strategic task about as defined by APM Terminals commented, "to influence the organization positively, find the weak spots, be the critical voice of conscience, facilitate debate and dialogue, challenge old ways of working and making the organization think and act differently [37]". As a result, all these precautions were expected to work as the number of fatal accidents in 2013 was reduced to three; that year was the second best year of the social sustainability performance of APM Terminals. Safety and zero fatality goal of APM Terminals continued to be the top priority in 2013; traffic, working at heights, falling objects, and stored energy defined as the main safety risks at the terminals. Necessary action plans were created to prevent accidents caused by these four risks and achieve the zero fatality target [38]. As shown in Figure 4, fatalities subdimension is the most important subdimension in social sustainability. Unfortunately, the year 2014 was the worst year of APM Terminals in fatalities with ten deadly accidents; thus, their social sustainability performance showed a sharp decrease. In 2014 they analyzed those fatal accidents, and they defined 5 fatal areas in the port, which are "transportation, suspended loads and lifting, working at heights, stored energy and contractor". When they defined these areas, they developed the "Fatal 5, a set of global operating standards," and made it mandatory to use all APM Terminal facilities [39]. This practice must have been successful as it seems that the number of fatal accidents has decreased considerably in the following years. In 2015, the port continued its "Fatal 5 " campaign developed with new mitigating efforts such as; "standardized risk management principles, man and machine separation, performance criteria for equipment, new equipment, focusing on enhancing people capabilities and skills $[42,46] "$. In 2016, fatality issues and safety were on the agenda again, and they continued to develop the "Fatal 5" program [45]. In addition to that transition from materiality matrix to materiality model, the best social sustainability performances have ever been achieved along with environmental performance. Safety continues to number one priority for APM Terminals in 2017 too. In some terminals, they started to use drones to some tasks such as looking at traffic flows, monitoring container stack efficiency or unsafe behavior, filming the site operations, etc. And they assessed the results as success and improvement of safety culture [47].

\section{Conclusions}

This work consisted of AHP and TOPSIS methods for a case company to detect the important degree of ports sustainability criteria, decide the port sustainability performance with the light of this important degree, and the possible reasons for port sustainability performance inequalities to all three dimensions of sustainability. Based on results, the importance regarding the degree of sustainability dimensions is determined as financial dimension, environmental dimension, and social dimension. Besides, the most important subdimension for each dimension is determined as operating profit for financial dimension, water consumption for environmental dimension, and fatalities for social dimension.

Financially, it has been observed that they have experienced a steady decline since 2014 . And the financial improvement in 2014 was mostly impacted by the sale of some APM Terminal facilities. In 2017, the only negative operating profit value was reported over the years studied. After that, Maersk Group stopped publishing separate reports for APM Terminals and published them by combining the group reports; thus, it was not possible to observe the performance after 2017. Since APM Terminals serve simultaneously in many different regions of the world, it has become very sensitive to global risks and threats. Risks and threats arising from the falling in oil prices, and structural challenges due to larger container vessels, shipping lines consolidations, and alliances, have been felt more than others in certain regions of the world. However, for APM Terminals, it has been found that it negatively affects its entire performance.

When the environmental sustainability performance is analyzed by years, it has been determined that the graph tends to increase except for the years that can be considered as exceptions. Even if a slight decrease was observed in 2017, the value was higher than all other years except 2016, facing difficulty to evaluate that as a failure. The main reason behind the success of environmental sustainability performance is thought to be the system that was first developed as a materiality matrix in 2012 and upgraded as a materiality model in 2016. Because the materiality matrix, which began to be used in 2012, provided the highest performance ever, 
and the transition to the materiality model in 2016 has resulted in the highest performance to date.

When it comes to social sustainability performance, fatalities are the main subject of APM Terminals. Because of these deadly accidents, they reported their worst performance in 2014. In the same year, they identified 5 areas where fatal accidents were experienced intensely in the port as transportation, suspended loads and lifting, working at heights, stored energy, and contractor and developed a "Fatal 5" campaign. Within the scope of this program, they started to focus on training programs and in-port improvements. And even in the following years, they started working with drones in some pilot areas to find a solution to the problem of working in the heights. As a result, the number of fatal accidents has decreased considerably in the following years. In addition to the Fatal 5 program, the transition from materiality model that explained in environmental performance caused their best social sustainability performances ever due to the safety elements in the model.

Besides, while measuring the sustainability performance of the selected port, nine criteria suggested for port sustainability performance measurement in the literature have been used [17,23-25]. As a result of the study, it was determined that if the sustainability performance of the examined port was analyzed according to these criteria, significant increases and decreases in the sustainability performance could be observed. With this finding, the study in question supports the accuracy of the port sustainability measurement criteria suggested in the literature $[17,23$ 25].

The APM Terminals, which were examined within the scope of the study, changed their reporting format after 2017 and started to publish data on all of the group companies, causing the study to be planned to cover only for seven years. Since sustainability performance is a phenomenon that is expected to improve over the years due to its nature, the most important limitation of the study is that the performance for post-2017 cannot be examined. Besides, there is no standard format for port sustainability report that allows all analyzes to be made exclusively for ports but does not allow performances of more than one port to be compared. In this context, it is recommended to develop a standard format for port sustainability reports for future studies. As a result of the study, it was concluded that systems such as the "Fatal 5 program" and "materiality model" developed and implemented by APM Terminals positively affect the sustainability performance of the ports. It is thought that conducting in-depth researches on these systems would contribute to the existing literature and benefit industry practitioners.
Funding: The author declared that this study received no financial support.

\section{References}

[1] T. Kuhlman, and J. Farrington, "What is sustainability?" Sustainability, vol. 2, pp. 3436-3448, 2010.

[2] M. Taşçıŏlu, “Consumers' perceptions towards sustainability: A cross-cultural analysis." Electronic Theses and Dissertation, Statesboro, Georgia: Georgia Southern University; 2014.

[3] J. E. Moore, A. Mascarenhas, J. Bain, and S. E. Straus, "Developing a comprehensive definition of sustainability," Implementation Science, vol. 12, pp. 110, September 2017.

[4] H. D. Kuş, "Sustainable supply chain management application to Turkish construction industry." [Unpublished master's thesis]. İstanbul: Fatih University Institute of Sciences and Engineering; 2012.

[5] G. H. Brundtland, "Report of the world commission on environment and development: our common future," United Nations: 1987.

[6] J. F. Henri, and M. Journeault, "Eco-control: The influence of management control systems on environmental and economic performance", Accounting, Organizations and Society, vol. 35, pp. 63-80, January 2010.

[7] J. Elkington, "Cannibals with forks. The triple bottom line of $21^{\text {st }}$ century," Journal of Business Ethics, Capstone Publishing Limited, Oxford, 1997, pp. 402.

[8] B. Moldan, S. Janoušková, and T. Hák, "How to understand and measure environmental sustainability: Indicators and targets," Ecological Indicators, vol. 17, pp. 4-13, June 2012.

[9] A. Eş, "Sürdürülebilirlik ve firma düzeyinde sürdürülebilirlik performans ölçümü. [unpublished master's thesis]. Bolu: Abant İzzet Baysal University Institute of Social Sciences, 2008.

[10] P. Bansal, "Evolving sustainability: A longitudinal study of corporate sustainable development," Strategic Management Journal, vol. 26, pp. 197-218, December 2005.

[11] E. Nemli, Sürdürülebilir Kalkınma: Şirketlerin Çevresel ve Sosyal Yaklaşımları, Filiz Kitabevi, İstanbul, 2004, pp. 206.

[12] J. M. Harris, “Basic principles of sustainable development," Global Development and Environment Institute, Working Paper: 00-04, USA: Tufts University, June 2000.

[13] T. Daamen, "Sustainable development of the European port-city interface," in ENHR-conference Rotterdam, June 25-28, 2007, pp. 1-20.

[14] K. A. Abood, "Sustainable and green ports: Application of sustainability principles to port development and operation," In Ports 2007: 30 Years of Sharing Ideas: 1977-2007, March 25-28, 2007.

[15] J. S. L. Lam, and E. Van de Voorde, "Green port strategy for sustainable growth and development," In Transport Logistics for Sustainable Growth at a New Level, International Forum on Shipping, Ports and Airports [IFSPA], 27-30, 2012.

[16] T. C. Lirn, Y. C. Jim Wu, and Y. J. Chen, “Green performance criteria for sustainable ports in Asia," International Journal of Physical Distribution \& Logistics Management, vol. 43 pp. 427-451, June 2013. 
[17] E. Peris-Mora, J. D. Orejas, A. Subirats, S. Ibáñez, and P. Alvarez, "Development of a system of indicators for sustainable port management," Marine Pollution Bulletin, vol. 50, pp. 1649-1660, August 2005.

[18] Y. Çınar, "Çok nitelikli karar verme ve bankaların mali performanslarının değerlendirilmesi örneği [published master thesis]." Ankara Üniversitesi Sosyal Bilimler Enstitüsü, 2004.

[19] S. Zionts, "MCDM-If not a roman numeral then what?" Interfaces. vol. 9, pp. 94- 101, August 1979.

[20] M. Puig, C. Wooldridge, and R. M. Darbra, "Identification and selection of environmental performance indicators for sustainable port development," Marine Pollution Bulletin, vol. 81, pp. 124-130, April 2014.

[21] A. Öztel, M. S. Köse, and İ. Aytekin, "Kurumsal sürdürülebilirlik performansının ölçümü için çok kriterli bir çerçeve: Henkel örneği," Journal of History Culture and Art Research, vol. 1, pp. 3244, December 2012.

[22] www.apmterminals.com, [2020]. Our Company. https://www. apmterminals.com/en/about/our-company, 31.03.2020.

[23] D. Tanzil, and B. R. Beloff, "Assessing impacts: Overview on sustainability indicators and metrics," Environmental Quality Management, vol. 15, pp. 41-56, June 2006.

[24] M. H. Hakam, "Nordic container port sustainability performance: A conceptual intelligent framework," Journal of Service Science and Management, vol. 8, pp. 14-23, January 2015.

[25] T. A. Shiau, and C. C. Chuang, "Social construction of port sustainability indicators: A case study of keelung port," Maritime Policy \& Management, vol. 42, pp. 26-42, December 2015.

[26] T. L. Saaty, Fundamentals of decision making and priority theory with the analytic hierarchy process, Reprint. Original source: New York Public Library, RWS publications, 1994. 6th volume / AHP series Volume 6 / Analytic hierarchy process series, 2000. [Online] Available: Safari e-book.

[27] P. T. Harker, and L. G. Vargas, "The theory of ratio scale estimation: Saaty's analytic hierarchy process," Management Science, vol. 33, pp. 1383-1403, November 1987.

[28] A. Ishizaka, and P. Nemery, "Multi-criteria decision analysis: methods and software," Pages are shown courtesy of publisher: John Wiley and Sons. June 2013.

[29] T. L. Saaty, "A scaling method for priorities in hierarchical structures," Journal of Mathematical Psychology, vol. 15, pp. 234 281, June 1977.

[30] O. S. Vaidya, and S. Kumar, "Analytic hierarchy process: An overview of applications." European Journal of Operational Research, vol. 169, pp. 1-29, February 2006.
[31] T. L. Saaty, "Fundamentals of the analytic network process," In Proceedings of the 5th international symposium on the analytic hierarchy process, ISAHP 1999, Kobe, Japan, 12-14, August 1999.

[32] G. H. Tzeng, and J. J. Huang, Multiple attribute decision making: methods and applications, London: New York, CRC press. 2011.

[33] M. Yurdakul, and İ. Ç. Yusuf, "Türk otomotiv firmalarının performans ölçümü ve analizine yönelik TOPSIS yöntemini kullanan bir örnek çalışma," Gazi Üniversitesi MühendislikMimarlık Fakültesi Dergisi, vol. 18, pp. 1-18, 2003.

[34] Aykin, N. [Ed.]. Usability and Internationalization. HCI and Culture, Second International Conference on Usability and Internationalization, UI-HCII 2007, held as Part of HCI International 2007, Beijing, China, July 22-27, 2007, Proceedings [Vol. 4559]. Springer. 2007.

[35] H. Raharjo, and D Endah, "Evaluating relationship of consistency ratio and number of alternatives on rank reversal in the ahp," Quality Engineering, vol. 18, pp. 39-46, June 2006.

[36] APMT SR, [2011]. APM Terminals Sustainability Report. Retrieved from: https://www.apmterminals.com/en/about/ sustainability

[37] APMT SR, [2012]. APM Terminals Sustainability Report. Retrieved from: https://www.apmterminals.com/en/about/ sustainability

[38] APMT SR, [2013]. APM Terminals Sustainability Report. Retrieved from: https://www.apmterminals.com/en/about/ sustainability

[39] APMT SR, [2014]. APM Terminals Sustainability Report. Retrieved from: https://www.apmterminals.com/en/about/ sustainability

[40] Maersk AR, [2012]. Maersk Annual Report. Retrieved from: https://investor.maersk.com/financial-reports

[41] Maersk AR, [2014]. Maersk Annual Report. Retrieved from: https://investor.maersk.com/financial-reports

[42] Maersk AR, [2015]. Maersk Annual Report. Retrieved from: https://investor.maersk.com/financial-reports

[43] Maersk AR, [2016]. Maersk Annual Report. Retrieved from: https://investor.maersk.com/financial-reports

[44] Maersk AR, [2017]. Maersk Annual Report. Retrieved from: https://investor.maersk.com/financial-reports

[45] Maersk SR, [2016]. Maersk Sustainability Report. Retrieved from: https://www.maersk.com/about/sustainability/reports

[46] Maersk SR, [2015]. Maersk Sustainability Report. Retrieved from: https://www.maersk.com/about/sustainability/reports

[47] Maersk SR, [2017]. Maersk Sustainability Report. Retrieved from: https://www.maersk.com/about/sustainability/reports 